\title{
CHARTERED ACCOUNTANCY AND RESISTANCE IN SOUTH AFRICA
}

\author{
J. Terblanche \\ Department of Accounting \\ University of the Western Cape \\ Cape Town, South Africa \\ e-mail: jterblanche@uwc.ac.za / https://orcid.org/0000-0002-5649-0083
}

\section{Y. Waghid}

Department of Education Policy Studies

Stellenbosch University

Stellenbosch, South Africa

e-mail: yw@sun.ac.za / https://orcid.org/0000-0003-2565-824X

\section{ABSTRACT}

In recent times, the chartered accountant profession was regularly in the news for reasons pertaining to the unethical and unprofessional behaviour of members. The profession has an important role to play in the South African economy, as members will often fulfil important decisionmaking roles in business. In a response to the dilemmas the profession is facing, we analysed the implications for the profession and society due to a resistance to include research as a pedagogical activity in the chartered accountancy educational landscape. Through deliberative research activities, students have the opportunity to engage with community members and with societal challenges that could foster reflexivity and humaneness in students. In addition, critical and problem-solving skills are cultivated. These are skills that are difficult to assess in the form of an examination, and the absence of research as pedagogical activity in this particular educational landscape, impacts the cultivation of these skills in future chartered accountants. This is so, as the chartered accountancy educational landscape is significantly influenced by the power that resonates within the profession and culminates into the disciplinary power mechanism of the examination. The South African Institute of Chartered Accountants (SAICA) set an external examination, called the Initial test of Competence (ITC), which graduates need to write upon leaving institutes of higher learning. Success in this SAICA-examination therefore impacts on the teaching and learning pedagogy adopted by chartered accountants in academe. If chartered accounting students were instead primarily being exposed to technical content assessed via an examination, also being exposed and introduced to deliberative research, the possibility exists that students, through critical reflexivity, could move beyond the constraints of the self to that of the communal other in line with the African notion of ubuntu can be enhanced.

Key words: chartered accountant, deliberative, higher education, encounter, examination, reflexivity, research, responsible leadership, social justice 


\section{INTRODUCTION AND BACKGROUND}

There is agreement that the functions of a higher education institution (HEI) could be grouped into that of teaching, research and community interaction (Leibowitz 2012). Van der Walt, Potgieter and Wolhuter $(2014,836)$ pertinently argue that research is "a form of pushing back the frontiers of knowledge and applying knowledge to the benefit of humankind". Based on this explanation, one could argue that the teaching and learning and research practices are working in tandem, and that both types of practices are needed in order to contribute to a society where the citizens are flourishing. Through teaching and learning practices, students (and educators) are engaging with recognised knowledge truths, and through research practices, new knowledge truths (that could or could not challenge recognised truths) are established that will influence the teaching and learning practices of the future.

The aim of teaching and learning and research is (or should be) for the benefit of society at large or, as often described in the educational context, for the "public good" (Walker 2010, 486). Differently put by Naval, Print and Veldhuis (2002:108) “[w]hat is required [from HEIs] are [to cultivate in students] the attitudes and capacity to engage in dialogue, respect, solidarity, tolerance and a sense of responsibility towards the common good of society and of humanity as a whole". For the "public good" in principal therefore implies democratically participative citizens that can look beyond themselves or their own needs and desires: that could address injustice and inequality still prevailing society; that could make ethical (business) decisions; and that could lead responsibly (that is to be held accountable). This is important as "the flourishing of each citizen is dependent upon the flourishing of other citizens, whether politically and socio-economically disadvantage or not" (Waghid 2003, 23). Therefore, HEIs in South Africa, could (and should) contribute towards fostering these required attitudes and capacity in students (citizens) through teaching and learning and research practices.

The purpose of this article is to explicate the possible consequences to the South African society as a result of reluctance to introduce research as a pedagogical practice into the curriculum for chartered accountant (CA) students. Firstly, we discuss the current reality in the CA educational landscape. Secondly, we focus on the purpose of pedagogical practices, with a specific focus of the benefits and value by utilizing research as a teaching and learning practice. Lastly, we argue what the possible implications and consequences for the South African society might be, as a result of the current power relation evident in the CA educational landscape. Next, we discuss the state of research activities in the South African CA educational landscape.

\section{CURRENT REALITY: THE CHARTERED ACCOUNTANT EDUCATIONAL LANDSCAPE}

Waghid, Waghid, and Waghid $(2018,132)$ warn: 
"Recently, we have become concerned with the lack of research production and lack of students who have the critical human agency both to question freely and to assert themselves authoritatively, and also concerned about academics [educators] who do not enter the fray of critical engagement through awareness and listening."

This warning reverberates loud and clear in the South African CA educational landscape. The South African Institute for Chartered Accountants (SAICA) issues a prescriptive competency framework (CF) applicable to the HEIs that are accredited by SAICA to provide undergraduate and/or postgraduate programmes. Students enrolling for these accredited undergraduate or postgraduate programmes aim to become chartered accountants of South Africa in the near future, also known as CA(SA)s. The CF lists detailed competencies that students should have acquired upon leaving the HEIs. As part of the ongoing monitoring of the accreditation process, SAICA conducts accreditation visits at HEIs. During these monitoring visits, HEIs need to prove how they teach towards these competencies (as contained in the CF) and also how they assess whether these competencies were in fact developed by the students. According to SAICA, the responsibility to ensure that all the competencies contained within the $\mathrm{CF}$, are developed sufficiently by students to enter the profession, lies undeniably with HEIs (StraussKeevy 2014). Irrefutably, the profession, through SAICA, has a profound influence on the knowledge being taught and the teaching and learning practices utilised by educators in the CA educational landscape. This influence of the profession is evident through the accreditation process and the pre-scribing of a CF with detailed outcomes. Terblanche (2019) identified, in line with Foucauldian thought, that these (the accreditation process and the detailed CF) are two of the three disciplinary power mechanisms employed by the profession to exercise power over the CA educational landscape.

The significant power of the profession on the curriculum, through the $\mathrm{CF}$, is detrimental to the development of problem-solving and critical skills, as well as to the fostering of socially responsible CA(SA) citizens (Lubbe 2013). The technical complexity and sheer volume of the content as prescribed by the $\mathrm{CF}$ poses a significant challenge to educators teaching on the SAICA-accredited programmes. In addition, the classes are often large and the students are underprepared for higher education due to the problematic schooling system (Lubbe 2013). All these factors often result in teaching and learning pedagogical practices that are focused on the educator imparting knowledge to the student, rather than participative practices where the conditions for human engagement and human emancipation could be fostered (Wood and Maistry 2014). Educators often explain technical content as per legislation or accounting and auditing standards, rather than engaging in dialogue with the students about the implication of 
this content on society. The nature of the technical content is primarily focused on the private sector.

The third disciplinary power mechanism evident in the CA educational landscape in line with Foucauldian thought, as identified by Terblanche (2019), is that of the examination. One of the reasons why educators teaching on the SAICA-accredited programmes often pursue the outcomes (competencies to be developed upon leaving the HEI) as per the CF religiously, is because successful postgraduate students write an examination, set by the profession, shortly upon leaving the HEI (Venter and De Villiers 2013). This examination is used by the profession to determine whether the student has developed all the competencies required to enter the profession, successfully. This examination is called the Initial Test of Competence (ITC).

Unmistakably, the results of the ITC examination are of essence for the graduate of an $\mathrm{HEI}$, as the prospective $\mathrm{CA}(\mathrm{SA})$ desires to become part of the profession and earn then the right to use the $\mathrm{CA}(\mathrm{SA})$ designation. Likewise, the results of the ITC examination are important for HEIs as there is significant competition between HEIs to earn the right of being the top performer among accredited HEIs. The results of the ITC examination are widely published and indicate the pass rate (and thus success) of each accredited HEI. Good results in an ITC examination often lead to a possible increase in student applications to study at that particular HEI, as students want to be prepared by their HEI of choice in such a way, that they are ready to be successful in the ITC examination (Venter and De Villiers 2013). Student choice could therefore often be influenced by the perception of success, measured as a pass rate, rather than the holistic care for students or institutional identity of the HEI. Venter and De Villiers (2013) argue that accredited departments of Accounting align their teaching and learning practices with that of the ITC examination. Deliberations about improving the results of graduates in the ITC examination often take central stage in departmental and subject-specific meetings, while hardly any discussion occurs pertaining to matters such as responsible citizenship or different pedagogical approaches to foster a socially just consciousness (Venter and De Villiers 2013). In essence, the focus in accredited departments of Accounting is thus skewed towards success in the professional examination, rather than towards the development of socially responsible citizens.

Lubbe $(2013,88)$ correspondingly claims, "[t]he attempts by universities to maximise the performance of their students in the professional bodies' examinations result in university accounting degrees imitating professional qualifications by placing particular emphasis on learning techniques, rules and regulations". Therefore, students are coached to pass examinations that mimic the examination set by the professional body by adopting a pedagogical style of "teaching-towards-the-test". Waghid $(2017,24)$ rightly argues that, due to 
the demands of a market economy, the risk exists that students (inclusive of future CA(SA)s) might leave HEIs as mere "technicians of learning". Waghid (2017) defines "technicians of learning" as students who are dependent on their educators for their learning. "Technicians of learning" are therefore students who lack the skills set to act autonomously, and who are unable to connect knowledge to the solving of societal problems, but are able to apply the technical knowledge diligently without considering the implications of their decisions on society (Waghid 2017). Without the skills to act autonomously, students (and thus the future CA(SA)s) will find it challenging to initiate change inside and outside of their field of expertise.

McPhail (2001) posits that the risk exists that students with a Western and capitalistic world view are aligned to achieve greater success in becoming CA(SA)s compared to students with a communal perspective on life. In the South African context, this is important, because the country is still trying to rid itself from the shackles of its discriminatory and unequal past. Students from predominantly previously disadvantaged communities voiced this feeling of alienation they experienced, through the students protests, under the banners of \#RhodesMustFall and \#FeesMustFall that swept through university campuses across South Africa during 2015-2016. The alienation that students experienced, evident through the call for the decoloniality of the curriculum, was not just associated with campus buildings and statues, but amongst other factors, also with the structures, processes, institutional culture, teaching and learning practices and curriculum content (Mbembe 2015). The risk exists that within the CA educational landscape, we perpetuate inequality by associating worth (essentially human dignity) with the passing of examinations that prescribe a particular world view.

SAICA is dedicated to produce technically skilled $\mathrm{CA}(\mathrm{SA}) \mathrm{s}$ who will practice "responsible leadership" (SAICA 2017, 6) to advance the South African economy, and by doing so contribute to social justice and future social cohesion. The past two years the profession and the South African society at large were shocked, as several instances of corporate failures and state capture were reported. CA(SA)s were implicated as key masterminds in several of these instances. Perhaps there is no better time than now to consider possible changes to the CA educational landscape. More so in relation to "responsible leadership" than in terms of the pure technical side. Klaus Schwab (2018), the founder and executive chairperson of the World Economic Forum (WEF) states:

"In the 47 years since I founded the World Economic Forum, I have witnessed first-hand that when we change the way we talk, we begin to think differently too. Likewise, changing the way we think leads to changes in the way we act. This is true for all of us - whether you are a private citizen at home or making consequential decisions as a head of government, the language we use and the way we think about the world shapes our subsequent behaviour." 
As a consequence of and in response to Schwab's (2018) statement above, the conversation within the profession and within the educational landscape should change. In order for members of the accountancy profession to change their behaviour, to act responsibly and just, and to pursue social justice for all, they need to change the way they think (Terblanche 2019). Thinking will be influenced by discussion and dialogue that lead to deliberation. Deliberative encounters and critical conversation about the meaning of responsible leadership in an unequal society should thus be created. One such space, for changing the future CA(SA), is the educational landscape - specifically so in relation to research. Research as a pedagogical activity within education, has the potential to create deliberative encounters and instigate change.

However, in light of the highly technical content (and considerable volume) prescribed in the SAICA CF, students are not required to perform any research activities during their undergraduate or postgraduate qualifications. Research is therefore not a pre-requisite, a required competency so to speak, identified by SAICA for entering the profession. This absence of research skills listed in the CF results in accredited departments of Accountings at HEIs neglecting one of their primary functions and responsibility as educators. Instead of HEIs incorporating research as compulsory in their programmes, independently of the stance by the profession or the competencies listed in the $\mathrm{CF}$, they rather chose to change their postgraduate programmes from an honours degree (where research is compulsory) to a postgraduate diploma in accounting (PGDA) (where there is no compulsory research component). The pressure on the performance of their students in the ITC examination therefore leads educators at HEIs rather aligning with the profession than with educational principles (and respective HEIs policies) (Terblanche 2019). As a direct result of the prescriptive CF of the profession, students (possible future CA(SA)s) graduate at HEIs without any exposure to research, without the important skills set of conducting critical research, and without developing and enhancing problem-solving skills. As a result - also often without the development of reflexivity - they are thus unable to change the conditions for human engagement that will lead to a dignified and transformed lived reality for all.

In this section we highlighted how through particular disciplinary power mechanisms, the CA educational landscape is primarily focused on developing the required competencies as described by the profession and measured through a written examination. In the next section we briefly summarise some of the outcomes of pedagogical practices, with a specific focus on research. 


\section{PURPOSE OF PEDAGOGICAL PRACTICES IN HIGHER EDUCATION}

Leibowitz (2012) argues that the rightfulness of an HEI is embed in whether the institution truly contribute to society - exists so to speak for the "public good". This notion of for the "public good" requires that an HEI is calculated and thoughtful in its approach to achieve the desired outcome (Leibowitz 2012). One could reason that the desired outcome would be to create conditions for human engagement in such a way that the transformation and the traverse of internal, symbolic and physical boundaries become possible for students (and educators) to the extent that they actively pursue to right that which is wrong, to speak up about unjust practices, and to act responsibly themselves. HEIs therefore have the responsibility to ensure that the curriculum and teaching and learning practices employed in each programme are supportive in cultivating in students (and educators) a belief in social responsibility. Teaching and learning practices that create the conditions for human engagement and which instil a belief in social responsibility are extremely relevant to the South African context. The African notion of ubuntu declares that the greatest responsibility of individuals (citizens or students) is "to become more fully human" and to develop one's humaneness in such a way that it is dependent on entering "more deeply into community with others" (Le Grange 2012, 331). Leibowitz (2012) emphasises that teaching for the "public good", that is to evolve in one's humanity, is feasible in all programmes, also that of the professional fields, such as accountancy or engineering.

Lotz-Sisitka et al. $(2015,73)$ posit, "[k]nowledge of issues is in and of itself inadequate", and the pedagogical practices incorporated by HEIs should result in students firstly becoming aware of societal injustice, noticing it so to speak, and secondly, responding to injustices. Inevitably, South African HEIs, in response to the complex challenges of this particular disparity context - a country that is still haunted by its Apartheid past and the continuance of perpetuated inequality and injustice - has to be able to recognise practices and conditions of injustice; otherwise, HEIs will not be able to incorporate suitable pedagogical practices into their educational programmes. According to Van der Walt et al. (2014, 843), higher education practices "should constantly endeavour to inculcate and encourage sustained critical consciousness in the minds of all [inclusive of educators and those in decision-making roles] involved about social justice issues".

As a result, such an awareness of a social justice consciousness could possibly only be engendered if the pedagogical practices are holistically orientated; that is practices that create opportunities for students to encounter diverse communities and diverse societal challenges where they can apply their knowledge in pursuit of solving particular lived problems to improve the lived reality of fellow citizens. Without a doubt, through such encounters between students and the lived challenges in communities, reflexivity is fostered in students (Leibowitz 2012). 
Students therefore become active participants in their own educational process and can participate in the creation of possible new knowledge that could contribute to future flourishing lives.

The University of Pennsylvania implemented a research project where HEIs worked in partnership with schools and the community to endeavour to solve some of the challenges the community was facing (Saltmarsh 2007). Through this research project and community engagement, community problems were reduced and a sense of democratic responsibility was cultivated in the higher education students (Saltmarsh 2007). Saltmarsh (2007,69) rightly argues, "Penn[sylvania] has brought the questions of how do we know what we know and what is legitimate knowledge" into perspective, as knowledge earns validity and rightfulness through this practical ability to solve lived societal challenges.

Pedagogy that leads to this practical improvement of the lived reality of citizens and thus to social cohesion, is of paramount importance for South Africa. Fataar (2018) contends that, specifically pertaining to the South African context, students should be active participants in the educational process in order to make connections between the knowledge that is presented and the application of this knowledge in a familiar context. We argue that this connection between knowledge and the application to familiar contextual space is of importance, because in the South African context, the educational space will be diverse thus providing the possibility for an encounter between the self and the other, but equally so, an encounter with unknown diverse lived societal difficulties.

Such an encounter, which is extended beyond the classroom, will provide students with the possibility to notice inequality and injustice, the first requirement in becoming a socially just and responsible citizen (student). Naudé (2017) states unequivocally that social cohesion could only become an actuality in democratic societies where the plight of the marginalised is noticed. Citizens (students) should therefore comprehend the implications of an unequal world. "Confronting and acting on inequality provides that 'collective space of anguish' and also the clear demand for collective social action towards resolution" (Maré 2017, 47). Educational encounters that allow for interaction between the privileged and the marginalised, therefore create the possibility to engender compassion. Compassion is the essential ingredient to entice an individual (student or citizen) to progress from noticing injustice to actively responding to injustice. Educational encounters that allow for an interaction between knowledge (as per the particular discipline, such as accounting) and the lived reality of citizens, create the opportunity for students to be meaningfully challenged and enriched as reflexivity and compassion are provoked (Zipin 2017).

Thomson and Bebbington (2004) reason that, through the introduction of research 
activities into an accounting undergraduate programme, reflexivity was cultivated in students participating in their research. The students had to identify research problems, which often related to societal or environmental problems they had encountered themselves (Thomson and Bebbington 2004). Solving or an attempt to contribute to the improvement of this particular lived challenge, became real and important to the students as they were invested in their familiar identified research challenge. In essence, students therefore often draw upon their embodied knowledge, when research as pedagogy is used in the educational process.

Furthermore, Mahlomaholo (2014) explicates that research as pedagogical activity creates opportunities for students (and their knowledge) to engage with the lived realities and current communal difficulties. HEI researchers (educators) "become visible public intellectuals engaging with social and community issues" (Mahlomaholo 2014, 679), whilst students (and educators alike) are provided with an opportunity to open themselves up for meaningful transformation. Such encounters encourage social cohesion as democratic principles are nurtured and individuals are opened up to notice injustice. "Putting knowledge to work on a problematic [societal challenge] - which both uses and (re)makes knowledge - generates working solutions" and in this way, education as a process becomes simultaneously participative and transformative by nature (Zipin 2017, 77) (original emphasis). In addition, through this collaboration between HEIs and communities with a focus on the challenges experienced by marginalised individuals, human dignity is restored as the marginalised individuals (and the problems they experience) are recognised by the educators and students; the marginalised individuas are deemed (and redeemed) valuable and worthy.

Zipin, Fataar, and Brennan (2015, 21-22) argue, "[s]cience-worlds, then, ought not to aspire to leave life-worlds behind in determining where new knowledge might matter. Rather, they need continuing contact with the life-breath of newly emergent problems and associated sense-makings from life-worlds, or they become static." In this sense, Zipin et al. (2015) argue for the recognition of how the teaching of knowledge and research activities pertaining to societal challenges are intertwined, and therefore, the outcome of a meaningful educational process is reliant on both these practices working together. Zipin $(2017,75)$ claims, "[s]uch lived problems can spur powerful spontaneous thought in the conceptual repertoires of students' and even the wider community", and therefore research as a pedagogical activity becomes an empowering element for true change.

Change, social cohesion and social justice are all notions the South African society desperately needs. It is thus of importance that students at South African HEIs be exposed to research activities during the educational process in order to cultivate a social consciousness and to develop and enhance problem-solving abilities. Having citizens with the competency 
and the will to solve societal problems is pivotal for the South African democracy. In the next section, we elaborate on the possible consequences for society as a result of the absence of research as pedagogical activity in the CA educational landscape.

\section{POSSIBLE IMPLICATIONS FOR SOCIETY DUE TO THE LACK OF RESEARCH AS PEDAGOGICAL ACTIVITY}

Earlier, we identified that neither the accredited undergraduate qualifications nor the postgraduate qualifications at HEIs are required to include any formal research component. This lack of a structural research component, we argued, is detrimental to the CA educational landscape, as graduates firstly leave HEIs without the vital skills set that assists in problem solving, especially problems associated with the lived reality of marginalised citizens. A lack of such deliberative encounters and collaborations between the educators, students and community members, inhibits the development of reflexivity in students (and educators). In order for students (and educators) to participate in meaningful research activities, they should be open to the lived difficulties experienced by community members (Terblanche 2019). In that way, students (and educators) are moving from "listening to others to listening with them" (Hansen 2011, 116) (original emphasis). Hansen $(2011,166)$ asserts that listening with others can be defined as "an imaginative, aesthetic exercise of trying to see the world as they do, to try to grasp the underlying values, beliefs, and aspirations that inform their ways of looking and knowing". Through listening with others, students (and educators) cultivate reflexivity. Students (future CA(SA)s) who are willing to reflect - on their knowledge, on their behaviour, on the outcome of decision-making, on their world view, on privilege, on injustice and inequality - are the students who could possibly be transformed into responsible leaders who will act ethically. In addition, listening with others in such a manner fosters humaneness in students (and educators) and shifts the approach to that of a communal view rather than an individual perspective in line with the notion of $u b u n t u$ - that is of human dignity and recognition (Davids and Waghid 2018; Hansen 2011; Le Grange 2012; Waghid and Davids 2019). Through individual members of the CA profession, working in academe, that is collectively resisting the incorporation of research as pedagogical activity, society are consequently missing out on a powerful deliberative transformation potential.

Secondly, as we highlighted earlier, there is a particular relationship between the teaching of knowledge and the challenge and affirmation of this knowledge through the establishment of new knowledge as a result of research. As the CA educational landscape is rather barren in relation to pedagogical research, students rarely witness or partake in how new knowledge is constructed (Terblanche 2019). In part, this is a result of the teaching of volumes of highly 
technical content (as prescribed by the $\mathrm{CF}$ ), which leads to teaching and learning practices that focus on the explanation of technical interpretations rather than on the questioning and critical analysis of the underlying concepts embedded in the knowledge, policies, procedures and the influence of these on society. Students (and future CA(SA)s) therefore miss the opportunity to bring content knowledge in conversation with their lived reality. Seldom in the CA educational landscape is the focus on the why relative to technical knowledge. Considering the why enhances the possibility to develop a reflective capacity that could lead to a socially just consciousness that could infuse ethical behaviour (Hamilton 2007). Hamilton (2007) argues that considering the why could lead to the engendering of an ethical decision-making ability as a response to social accountability. This unchallenged acceptance of knowledge hamper the development of critical thinking, and future $\mathrm{CA}(\mathrm{SA}) \mathrm{s}$ will consequentially find it challenging to adopt strategies that would lead to ethical change. Based on their qualifications, future CA(SA)s will most likely play a leadership role in business. South Africa requires that business leaders make ethical decisions that will drive the economy and change the social reality of millions. As drivers for change, CA students should gain the opportunity to engage critically with knowledge content, as that will be a requirement of their future role in society. Being responsible leaders should become the intimate identity of $\mathrm{CA}(\mathrm{SA}) \mathrm{s}$. In becoming responsible leaders of the future, students need to engage critically with knowledge and encounter deliberative research activity where knowledge could be validated in the sight of societal difficulties.

Thirdly, it is primarily $\mathrm{CA}(\mathrm{SA}) \mathrm{s}$ who teach on the SAICA-accredited programmes (Venter and De Villiers 2013). If students are not exposed to structured research activities during their studies, the implication is that $\mathrm{CA}(\mathrm{SA}) \mathrm{s}$ joining the academe will be without this required skills set (Terblanche 2019). HEIs in South Africa are pre-dominantly research-led institutions, however as a result of the lack of structured research activities, department of Accounting staff will contribute very little to the development of new knowledge and to the research output of the HEI. "The primary functions of universities, namely to advance, develop and disseminate knowledge, and promote scholarship" are therefore rigorously affected in accredited departments of Accounting at HEIs (Verhoef and Samkin 2017, 1372). SAICA's interpretation of research compounds the problem, as from their perspective, scholarship (research) "includes consultation work and participation in standard setting, provided these do not impact the nature and quality of the accredited university programme" (Verhoef and Samkin 2017, 1372). Current educators are therefore not encouraged to participate vigorously in research after they join the academe, partly because of the view of the profession, but primarily due to high teaching loads in order to cover the volumes of technical knowledge contained in the CF (Wood and Maistry 
2014). Furthermore, the opinion exists "that new knowledge in Accounting is not created in the university, but rather in business, by the profession, and more specifically, by the committees and sub-committees of the International Accounting Standards Board (IASB)" (Lubbe 2013, 110). As a consequence, CA educators do not believe that they can contribute to the development of new knowledge, principally new knowledge that is valued by CA(SA)s working in business (Lubbe 2013). This problem exists due to the narrow view of knowledge only in relation to technical content, rather than realising that:

"South Africa currently experiences economic, social, and political problems including corruption at all levels of the public and government sector, major environmental and biodiversity concerns, and the legacy of apartheid, including transformation issues and social reconstruction. All these are worthy of sustained research by South African accounting academics" (Verhoef and Samkin 2017, 1388).

In this section, we have highlighted three possible consequences for society at large due to the absence of structured research pedagogical activities in the CA educational landscape.

\section{CONCLUDING REMARKS}

The power associated with the ITC examination - the external examination that graduates need to write when leaving HEIs - drives the CA educational landscape. Accredited departments of Accounting are concerned about their performance in the examination (based on the pass rate of graduates) and the consequent ability to attract students. In addition, as part of the accreditation process performed by SAICA, the ability of the HEI to teach and assess the competencies contained in the SAICA CF, measured as an outcome of the pass rate of students in the ITC examination, is regularly monitored. As a result, departments of Accounting align their programmes, content and assessment to mimic that of the CF in order to possibly achieve greater or continued success in the ITC examination. This drive of the CA educational landscape at HEIs to perform well in an external examination comes at a cost, not only to the profession, but also to society at large.

Educators in accredited departments of Accounting fail to adhere to the educational mandate, that of educating holistically, to the development of the full humaneness of the student; thus, for the "public good". South Africa (and the world) needs citizens who are willing to engage with practices of injustice and inequality, to make ethical decisions and to lead responsibly, whilst performing their duties in a professional manner. The South African society is still reeling from the unethical behaviour and decisions of $\mathrm{CA}(\mathrm{SA}) \mathrm{s}$, which resulted in a loss of trust but also financial loss to many. It is therefore imperative, that the CA educational 
landscape educate in line with the notion of "for the public good", which could otherwise be described in the $\mathrm{CA}(\mathrm{SA})$ context as teaching towards the cultivation of responsible business leaders or socially just democratic citizens.

Research as a pedagogical activity - currently not a requirement in the SAICA-accredited undergraduate or postgraduate programmes - could create opportunities by which students could be transformed to look beyond the individual self to the collective marginalised other. To our mind, students need to validate knowledge critically through encountering lived difficulties in society. Through this validation of knowledge exercise (research encounter), students would develop the capacity to analyse critically in order to derive at possible solutions to the communal problematic. This mind-set of solving societal issues would assist the student in her or his future role, as $\mathrm{CA}(\mathrm{SA}) \mathrm{s}$ will often be operating in decision-making capacities. Future decisions could therefore be aligned to instigate change - for the business, but also for the benefit of society and the environment. Substantial research vigour should be invested by $\mathrm{CA}(\mathrm{SA})$ educators pertaining to matters emphasising economic and societal problems. Financial choices, strategies and management affect the South African economy and society, and it is of importance that $\mathrm{CA}(\mathrm{SA}) \mathrm{s}$ are equally concerned about societal challenges that are perpetuated through such financial decisions and practices.

It is imperative that the CA educational landscape include and prioritise research as pedagogical practice. Research matters, as through research, reflexivity is engendered in students (and educators), and this opens up the possibility for responsible CA(SA)s of the future.

\section{REFERENCES}

Davids, N. and Y. Waghid. 2018. "Higher education as pedagogical site for citizenship education." Education, Citizenship and Social Justice 11(1): 34-43.

Fataar, A. 2018. "Placing Students at the Centre of the Decolonizing Education Imperative: Engaging the (Mis)recognition Struggles of Students at the Post-apartheid University." Educational Studies 54(6): 595-608.

Hamilton, S. E. 2007. “Accounting for Identity: Becoming a Chartered Accountant.” PhD dissertation. University of Stirling.

Hansen, D. T. 2011. The Teacher and the World: A Study of Cosmopolitanism as Education. Oxon: Routledge.

Le Grange, L. 2012. "Ubuntu, Ukama, Environment and Moral Education.” Journal of Moral Education 41(3): 329-340.

Leibowitz, B. 2012. "Introduction: Reflections on Higher Education and the Public Good." In Higher Education for the Public Good: Views from the South, edited by B. Leibowitz, xvii-xxvii. Stellenbosch: SUN Press.

Lotz-Sisitka, H., A. E. J. Wals, D. Kronlid, and D. McGarry. 2015. "Transformative, Transgressive Social Learning: Rethinking Higher Education Pedagogy in Times of Systemic Global 
Dysfunction." Current Opinion in Environmental Sustainability 16: 73-80.

Lubbe, I. 2013. "Educating Accounting Professionals: Development of a Theoretical Framework as a Language of Description of Accounting Knowledge Production and its Implications for Accounting Academics at South African Universities." South African Journal of Accounting Research 27(1): 87-124.

Mahlomaholo, S. M. G. 2014. "Higher Education and Democracy: Analysing Communicative Action in the Creation of Sustainable Learning Environments." South African Journal of Higher Education 28(3): 678-696.

Maré, G. 2017. "What Social Cohesion? Binding through Shared Austerity." In Living Together, Living Apart? Social Cohesion in a Future South Africa, edited by C. Ballentine, M. Chapman, K. Erwin, and G. Maré, 45-54. Pietermaritzburg: University of KwaZulu-Natal Press.

Mbembe, A. 2015. "Decolonising Knowledge and the Question of the Archive." WISER. https://wiser.wits.ac.za/system/files/Achille\%20Mbembe\%20-\%20Decolonizing\%20Knowledge \%20and\%20the\%20Question\%20of\%20the\%20Archive.pdf (Accessed 11 May 2019).

McPhail, K. 2001. "The Dialectic of Accounting Education: From Role Identity to Ego Identity." Critical Perspectives on Accounting 12: 471-499.

Naudé, P. J. 2017. "Toward Justice and Social Transformation? Appealing to the Tradition against the Tradition." HTS Teologiese Studies/Theological Studies 73(3): 1-8.

Naval, C., M. Print, and R. Veldhuis. 2002. "Education for democratic citizenship in the new Europe: Context and reform." European Journal of Education 37(2): 107-128.

SAICA see South African Institute of Chartered Accountants.

South African Institute of Chartered Accountants. 2017. "2017 Nation Building Impact Report." https://www.saica.co.za/portals/0/documents/2017_SAICA_Nation_Building_Report.pdf (Accessed 7 April 2019).

Saltmarsh, J. 2007. "Review Essay. Dewey's Dream: Universities and Democracies in an Age of Education Reform: Civic Society, Public Schools, and Democratic Citizenship." Michigan Journal of Community Service Learning Fall: 65-70.

Schwab, K. 2018. "The Urgency of Shaping the Fourth Industrial Revolution.” World Economic Forum. https://www.weforum.org/agenda/2018/01/the-urgency-of-shaping-the-fourth-industrialrevolution/ (Accessed 4 May 2019).

Strauss-Keevy, M. 2014. "Education Programmes' Responsibilities regarding Pervasive Skills." Journal of Economic and Financial Sciences 7(2): 415-432.

Terblanche, J. 2019. "Cultivating Socially Just Responsible Citizens in Relation to University Accounting Education in South Africa." PhD dissertation. Stellenbosch University.

Thomson, I. and J. Bebbington. 2004. "It Doesn't Matter What You Teach?" Critical Perspectives on Accounting 15: 609-628.

Van der Walt, J. L., F. J. Potgieter, and C. C. Wolhuter. 2014. "Can Universities Meet their Mandate to be Socially Critical as well as Constructive?" South African Journal of Higher Education 28(3): 832-848.

Venter, E. R. and C. de Villiers. 2013. "The Accounting Profession's Influence on Academe: South African Evidence." Accounting, Auditing \& Accountability Journal 26(8): 1246-1278.

Verhoef, G. and G. Samkin. 2017. "The Accounting Profession and Education: The Development of Disengaged Scholarly Activity in Accounting in South Africa." Accounting, Auditing \& Accountability Journal 30(6): 1370-1398.

Waghid, Y. 2003. Education as virtue. Cultivating practical reasoning and compassion. Stellenbosch: Stellenbosch University Publishers.

Waghid, Y. 2017. "Educate for Real Change.” Mail \& Guardian, June 9, 2017. https://mg.co.za/article/ 2017-06-09-00-educate-for-real-change (Accessed 11 November 2017). 
Waghid, Y., F. Waghid, and Z. Waghid. 2018. Rupturing African Philosophy on Teaching and Learning: Ubuntu Justice and Education. Cham: Palgrave Macmillan.

Waghid, Y. and N. Davids. (Eds.). 2019. African Democratic Citizenship Revisited. New York: Palgrave-MacMillan.

Walker, M. 2010. "A human development and capabilities 'prospective analysis' of global higher education policy." Journal of Education Policy 25(4): 485-501.

Wood, N. and S. M. Maistry. 2014. "Professional Accounting Associations' Influence on Higher Education Accounting Pedagogy." Alternation: 198-239.

Zipin, L. 2017. "Pursuing a Problematic-based Curriculum Approach for the Sake of Social Justice." Journal of Education 69: 67-92.

Zipin, L., A. Fataar, and M. Brennan. 2015. "Can Social Realism Do Social Justice? Debating the Warrants for Curriculum Knowledge Selection.” Education as Change 19(2): 9-36. 